\title{
Exploration of Groundwater Potential with Geoelectric Resistivity Method in Tanjung Kuba, Batu Bara Regency
}

\author{
Gustam Lubis ${ }^{1}$ \\ ${ }^{\text {I}}$ (Teknik Geologi, Institut Teknologi Medan, Indonesia)
}

\begin{abstract}
The geoelectric survey have been done to identify the potential of rock as a groundwater aquifer at Tanjung Kuba district Air Putih Batu Bara regency. The geoeletric measurements have been done at three points of vertical electrical sounding (VES) by using Sclumberger configuration with 150 to 200 meter of current electrode spacing $(A B / 2)$ and 0,5 to 10 meter of potential electrode spacing $(M N / 2)$. Interpretation of the resistivity value resulted that cover layer has resistivity value of 140 to $232 \mathrm{ohm}-\mathrm{meter}(\Omega / \mathrm{m})$, grave has 24,2 to 35 ohm-meter $(\Omega / m)$, sandy loam has 498 to 2081 ohm-meter $(\Omega / m)$, tuff has 38,5 to 141 ohm-meter $(\Omega / m)$ and the sand layer has 89,3 to $19785 \mathrm{ohm}$-meter $(\Omega / \mathrm{m})$. The presence of rock layers was interpreted as a layer of groundwater carrier (aquifer) with the presence of the confined aquifer (internal groundwater) at the sand layer with the good quality and hygienic at 82 meter depth with sand lithology.
\end{abstract}

Keywords: Geoelectric resistivity, aquifer

\section{Introduction}

Nowadays, the groundwater act as a renewal natural resources that play as an important role to providing water for the various purposes and caused a changes value of groundwater in market. Previously, the ground water is a free stuff that can be used freely without limits and control. However, the groundwater is high demands nowadays and caused the changed in value as well as becomes one of the economic goods that being traded as other commodities even in some areas the groundwater act as important role and determine the level of income of the community. The availability of the groundwater is limited for some period and place which make some district have a troublesome to find water with a perfect quality. In order to overcome this problem, the community should find an alternatives way to search the water resources especially the raw water and takes advantages of the underground water resources. One of the method that can be applied to find and estimate the layer of the groundwater carrier (aquifer) is geoelectric with utilizing the electrical properties that contained in earth especially its resistivity.

The purposes of this study are:

1. To determine the groundwater carrier (aquifer) rock distribution pattern in the study area.

2. To localized the groundwater carrier (aquifer) rock and use the groundwater in the study area.

3. To determine the hydrogeological condition in the study area.

4. To determine he depth of the groundwater carrier layer in the research area.

\section{Methodology}

Geoelectric resistivity method is one of the geophysical methods that used to determine the subsurface condition based on the resistivity value of the rocks. The purposes of the geoelectric survey is to quantify the resistivity value of the rock based on the measurement at the surface. The actual resistivity value can be obtained from the measurement value (Loke, 2004). This is the easiest and cheapest method that not required too high specification and software. The reading that can be obtained from this method are aquifer parameter, groundwater table depth, salinity rock permeability and bedrock (Siddalingamurthy, et al, 2014). Data acquisition have been done at three point in the Tanjung Kuba district Air Putih Batu Bara regency. The equipment that have been used during the field data acquisition is one-way resistivity tool Naniura Type NRD $22 \mathrm{~S}$ with $24 \mathrm{~W}$ power and voltage up to $450 \mathrm{~V}$. The measurement is done by using four electrodes, which are two current electrodes (A and B) and two potential electrodes (M and N). Schlumberger configuration as shown in Figure 1 are used with 0.5 to 10 meter potential electrode spacing (MN/2) and 150 to 200 meter current electrode spacing. Schlumberger configuration (Figure 1) have been used with potential electrodes spacing (MN/2) 0,5 to 10 meter and current electrodes spacing (AB/2) 150 to 200 meter. 


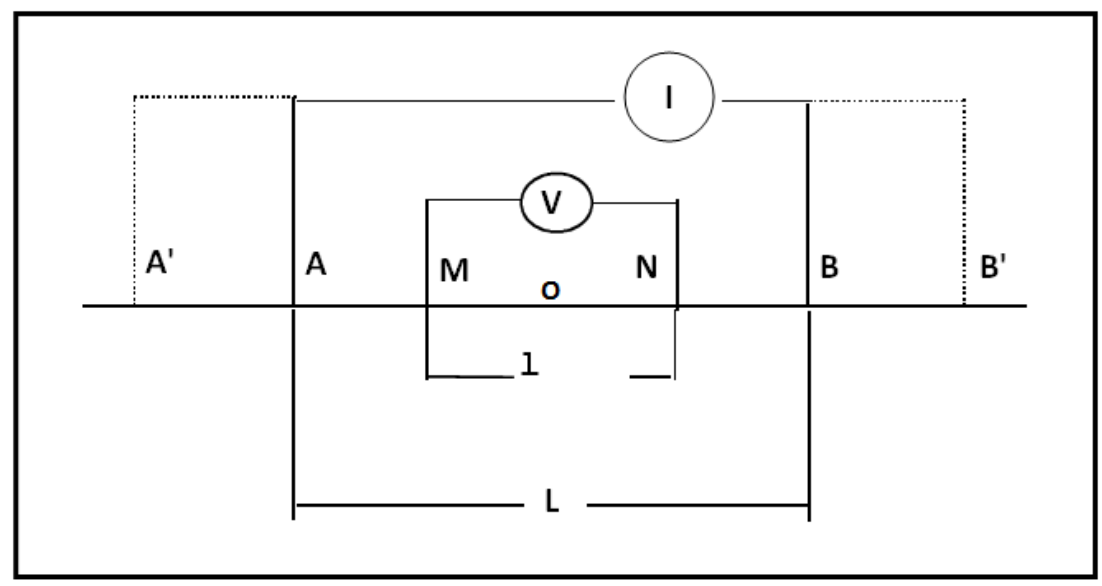

Figure 1: Schlumberger circuit model

The working principle of this method is by injected the electrode current $(\mathrm{AB})$ into the earth surfaces. The potential electrodes will measure the result of the potential difference from the current that flow through the layers of rock. The calculation of the apparent resistivity values is done by using the Ohm's Law. Resistivity values is affected by the current that flow through down the surfaces, the potential differences and the geometry factor. Apparent resistivity values can be calculated by using the equation (Telford and Sheriff, 1990).

$\rho=K \frac{\Delta V}{I}$

Where,

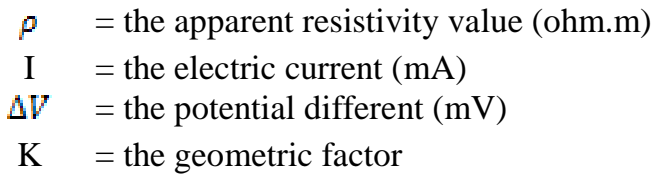

\section{Regional Investigation Geology}

Cuba are located at the Southeast part of the Medan city with UTM coordinates 524,074.364766. Based on Cameron et all (1982), the regional stratigraphy in the study area are composed by the oldest to the latest rock and is unit of the Toba Tufa $(\mathrm{Qvt})$ and deposits Alluvial $(\mathrm{Qh})$. Tuba tuff unit was arranged by a part of tuff riodasitan then with not aligned sedimented Alluvial (Qh) on top of it with a unit of rock which clay, sand and silt are dominant with loose and not compact characteristics. The alluvial unit is the result of destructed and transported from the preexisting rocks.

\section{Result And Discussion}

The geoelectric measurement have been conducted in Tanjung Kuba district Air Putih Batu Bara regency at three measurement points. The measurement points are located around the residents and agricultural areas.

Table 1: Resistivity value and lithology forecasts at the measurement area

\begin{tabular}{|c|c|c|}
\hline Resistivity $(\Omega / \mathrm{m})$ & Thickness $(\mathrm{m})$ & Lithology forecasts \\
\hline $140-232$ & $0-1$ & Top soil \\
\hline $24,2-35$ & 1 & Gravel \\
\hline $498-2081$ & $1-2$ & Sandy loam \\
\hline $38,5-141$ & $15-78$ & Tuff riodasitan \\
\hline $89,3-19.875$ & $48-82$ & Sand \\
\hline
\end{tabular}

Based on Table 1, the result can be interpreted as the lithological sequence order in Tanjung Kuba district Air Putih Batu Bara regency from the top to the bottom layer as follow:

Top soil: this layer has resistivity value range of 140 to $232 \mathrm{ohm}$-meter $(\Omega / \mathrm{m})$ and the thickness range between 0-1 meter from above ground. This layer is form due to the weathering and material destruction from the preexisting rock and available everywhere in the research area.

Gravel: this layer is indicated by the resistivity value range from 24.2 to $35 \mathrm{ohm}$-meter $(\Omega / \mathrm{m})$ and the range of thickness is 1 meter. The existence of this layer based on the measurement at point BB1 with $24.2 \mathrm{ohm}$-meter $(\Omega / \mathrm{m})$ resistivity value, BB2 with $31.7 \mathrm{ohm}$-meter $(\Omega / \mathrm{m})$ and BB3 $35 \mathrm{ohm}$-meter $(\Omega / \mathrm{m})$. 
Sandy loam: this layer has resistivity value of 498 to 2081 ohm-meter $(\Omega / \mathrm{m})$ and thickness varying from 1.0 to 2.0 meter.

Tuff riodasitan: this layer has resistivity value between 38.5 to $141 \mathrm{ohm}$-meter $(\Omega / \mathrm{m})$ with thickness varied from 15 to 78 meter. This layer due to the formation of Toba tuff which generally a constituent in the study area. Sand: this layer has resistivity value between 89.3 to 19.785 ohm-meter $(\Omega / \mathrm{m})$ with the depth start from 48 to 83 meter, but the thickness is not being sure due to the limitation of the devices ability in the electric current penetration. The existence of this layer based on the measurement result at point BB1 with the resistivity value of 19.785 ohm-meter $(\Omega / \mathrm{m})$, BB2 2105 ohm-meter $(\Omega / \mathrm{m})$ and BB3 $89.3 \mathrm{ohm}$-meter $(\Omega / \mathrm{m})$. This layer is estimated to be a groundwater carrier because of the porous (permeable) characteristic.

\subsection{Groundwater availability}

Based on the measurement and interpretation of electrical resistivity with the correlations of geological conditions of the study area, the layer of carrier water (aquifers) in the study area can be divided into two (2) types which are unconfined aquifer (unconfined aquifer) and confined aquifer (confined aquifer).

\subsubsection{Free aquifer layer (groundwater)}

Based on the interpretation of geoelectric and geological conditions in the study area, layer of the free aquifer consists of sandy loam and tuff. This layer encountered at the depth of 7 to 15 meter above the ground of the study area.

\subsubsection{Confined aquifer layer (internal groundwater)}

Based on the interpretation of geoelectric and geological conditions in the study area, layer of the confined aquifer is generally composed by a sand layer with tuff layer and sandy clay on top of it. The aquifer is located at the depth of 71 to 82 meter from the ground at the research area. The confined aquifer at this area have a good quality especially for the uses as a drinking water for the community because of its located at the very depth and have naturally gone a several filtration processes.

\section{Conclusion}

Tanjung Kuba district Batu Bara dominant are composed of Toba tuff with tuff riodasitan lithiology and deposited with alluvial layer on top of it by using clay, sand and silt lithiology. Result from geoelectric measurement and interpretation of resistivity value obtained: the cover layer has resistivity value of 140 to 232 ohm-meter $(\Omega / \mathrm{m})$, gravel is 24.2 - 35 ohm-meter $(\Omega / \mathrm{m})$, sandy loam $498-2081 \mathrm{ohm}$-meter $(\Omega / \mathrm{m})$, tuff 38,5 $141 \mathrm{ohm}$-meter $(\Omega / \mathrm{m})$ and sand layers 89.3 - $19.785 \mathrm{ohm}$-meter $(\Omega / \mathrm{m})$. The existence of the rock layer was interpreted as a layer of groundwater carrier (aquifer) with the presence of confined aquifer that act as water carrier which has the good quality and very hygiene at the depth of 82 meters which has permeable (shaft) characteristic. In order to meet the needs of drinking water, the community should take the advantages of the groundwater because it has a natural filtration system and the water is not contaminated.

\section{References}

[1]. Azhar dan Gunawan Handayani, 2004. Penerapan Metode Geolistrik Konfigurasi Schlumberger untuk Penentuan Tahanan Jenis Batubara. Bandung

[2]. David Keith Todd, 1980, Groundwater Hydrology, Toppan Company, Dobrin M.B,1967,Introduction to Geophysical Prospecting, Mc Graw Hill, New York

[3]. Fetter,1990. Applied Hydrogeology, University of Wisconsin, United States of America Fitch A. A,1981 Development in Geophysical Exploration Methods, Applied Science Publisher

[4]. Heru Hendrayana, 1994, Pemodelan Airtanah, Gadjah Mada Univiversity Press, Yogyakarta Loke, M.H.2014., Tutorial 2-D \& 3-D Electrical Imaging Surveys, http//www.geolectrical.com Nostrand. 1966. Interpretation of Resistivity Data. Washington: Geological Survey.

[5]. Siddalingamurthy,S., Nagaraju,D dan Balasuraramanian, A.,2014., Studies of Groundwater exploration In Chamaranjagar Taluk, Using Electrical Resistivity Tehniquies, International journal of Geology,Earth \& Environmental Sciences, pp 123-137

[6]. S.Mandel, Z.L. Shiftan, 1981, Groundwater Resources, Academic Press, New York, Telford, W. dan Sheriff,1990,Applied Geophysics, Cambridge University Press, London,

[7]. Zohdy,A.A,1989, New Methode for automatic Interpretation of schlumberger and winner sounding curves, Geophysic, pp 245-253 